\title{
Abundance of two Dendrocincla woodcreepers (Aves: Dendrocolaptidae) in relation to forest structure in Central Amazonia
}

\author{
Renato CINTRA ${ }^{1}$, Adrianny Erika MARUOKA², Luciano Nicolas NAKA ${ }^{3}$
}

\begin{abstract}
Few studies have been conducted to verify how the structure of the forest affects the occurence and abundance of neotropical birds. Our research was undertaken between January 2002 and July 2004 at the Reserva Ducke, near Manaus $\left(02^{\circ} 55^{\prime}, 03^{\circ} 01^{\prime} S\right.$; $\left.59^{\circ} 53^{\prime}, 59^{\circ} 59^{\prime} \mathrm{W}\right)$ in central Amazonia, to verify how the forest structure affects the occurrence and abundance of two bird species: the Plain-brown Woodcreeper Dendrocincla fuliginosa and the White-chinned Woodcreeper Dendrocincla merula. Bird species occurrence was recorded using lines of 20 mist-nets (one sample unit), along 51 1-km transects distributed along 9 pararel $8 \mathrm{~km}$ trails covering an area of 6400 ha. Along these transects, we placed $50 \times 50 \mathrm{~m}$ plots where we recorded forest structure components (tree abundance, canopy openness, leaf litter, standing dead trees, logs, proximity to streams, and altitude). We then related these variables to bird occurence and abundance using multiple logistic and multiple linear regression models, respectively. We found that $D$. fuliginosa frequently used plateau areas; being more abundant in areas with more trees. On the other hand, D. merula occurred more frequently and was more abundant in areas with low tree abundance. Our results suggest that although both species overlap in the reserve (both were recorded in at least $68 \%$ of the sampled sites), they differ in the way they use the forest microhabitats. Therefore, local variation in the forest structure may contribute to the coexistence of congeneric species and may help to maintain local alpha diversity.
\end{abstract}

\section{KEY WORDS}

Abundance, distribution, birds, Dendrocolaptidae, Dendrocincla, Amazon forest.

\section{O uso do habitat por duas espécies de arapaçus Dendrocincla (Aves: Dendrocolaptidae) em relação a estrutura da floresta na Amazônia Central}

\begin{abstract}
RESUMO
Em florestas neotropicais, poucos estudos tem sido conduzidos para verificar como a estrutura da floresta afeta o uso desse ambiente por aves. Este estudo foi realizado entre Janeiro de 2002 e Julho de 2004 na Reserva Ducke próximo a Manaus (02'55',0301'S; 5953',59059'W), para verificar como a estrutura da floresta afeta a ocorrência e abundância de duas espécies de aves: o Arapaçu-pardo, Dendrocincla fuliginosa e o Arapaçu-da-taoca, Dendrocincla merula. A ocorrência das espécies de aves foi registrada com 20 redes ornitológicas (unidade amostral), dispostas em linha contínua ao longo de cada um dos 51 transectos de $1 \mathrm{~km}$ distribuidos ao longo de nove trilhas pararelas de 8 $\mathrm{km}$ em uma área de $6400 \mathrm{ha}$. Em cada transecto foram demarcadas parcelas de $50 \times 50 \mathrm{~m}$, para registrar alguns componentes da estrutura da floresta (abundância de árvores, abertura do dossel, folhiço, troncos mortos em pé, troncos mortos no chão, proximidade de igarapés e altitude) os quais foram então relacionados com a ocorrência e a abundância das aves através de modelos de regressão múltipla logistica e múltipla linear, respectivamente. D. fuliginosa utiliza mais frequentemente áreas de platô, e a sua abundância foi maior em áreas com maior abundância de árvores. D. merula ocorreu mais freqüentemente e em maiores abundâncias em áreas com baixa abundancia de árvores. Os resultados sugerem que as duas espécies sobrepóem suas áreas de uso (ambas foram registradas em pelo menos 68,6\% dos locais amostrados), mas elas separaram-se no modo de uso do microhabitat. Portanto, a variação local na estrutura da floresta pode contribuir para a co-ocorrência de espécies congenéricas e deve ajudar a manter a diversidade alfa local.
\end{abstract}

\section{PALAVRAS-CHAVE}

Abundância, distribuição, aves, Dendrocolaptidae, Dendrocincla, Floresta Amazônica.

\footnotetext{
${ }^{1}$ Pesquisador do Departamento de Ecologia, Instituto Nacional de Pesquisas da Amazônia, Caixa Postal 478, Manaus.

${ }^{2}$ Bolsista do programa PCI (INPA-MCT).

${ }^{3}$ Mestre egresso do Curso de Pós-graduação em Ecologia-INPA.
} 


\section{INTRODUCTION}

Habitat structure and forest heterogeneity are believe to play a key role in organizing and structuring avian communities (MacArthur et al.,1966; Karr \& Roth,1971; Roth,1976; Martin,1985). Features of habitat structure or floristic composition can determine, among other things, availability of food, nesting sites, or refuge from predators. Due to its importance, ecologists have considered habitat features to be crucial components of birds' niches (Wiens et al., 1987).

The effects of habitat heterogeneity on bird populations and communities, however, have received far more attention in temperate regions than in the tropics (MacArthur \& MacArthur,1961; Karr \& Roth,1971; Wiens, 1974; Roth,1976; Rey, 1995), and the mechanisms that determine habitat use by bird populations in tropical rain forests are not well known.

Understanding how the structure of tropical forests vary is important to describe the bird community associated with them, and to recognize the mechanisms that allow the high species coexistence seen in these forests (Pearson,1977; Manasse \& Howe,1983; Martin,1985; Levey,1988; Loisselle,1988; Terborgh et al., 1990; Naranjo, 1992). Tropical forests, however, are complex environments, and detecting exactly what components of the vegetation affect the distribution, occurence, and abundance of birds is difficult.

Human-disturbed forests present a clear example of the importance of forest structure on the occurence of birds. It is known that selective logging has drastic effects on the vegetation structure, by reducing or increasing tree density, tree abundance, number of dead trees, canopy opening, etc. Therefore, it is very likely that changes in bird species richness and abundance in disturbed forests are mainly due to changes in some vegetation components, which could affect the availability of food resource and microclimatic conditions (Johns, 1991).

Primary or undisturbed forests also show a relatively high degree of environmental heterogeneity. The role of this heterogeneity is mostly unexplored, but can also affect the abundance and occurence of birds. Woodcreepers are believed to be sensitive to changes in forest structure principally when the abundance of trees is reduced (Thiolay, 1992; Guilherme \& Cintra 2001). Therefore, we believe that they represent a good study group to evaluate the effects of the forest environment on their distribution and abundance.

We selected two species of congeneric woodcreepers: the Plain-brown Woodcreeper (Dendrocincla fuliginosa) and the White-chinned Woodcreeper (Dendrocincla merula), which live in the middle and lower levels of lowland neotropical forests in similar types of forest, but differ in their ecology, the first being a solitary tree dweller that sometimes joins mixed-species flocks, and the second an obligate army-ant follower (Willis, 1979). We studied their abundance and occurence in a 10,000 ha reserve in Central Amazonia, and related their distribution with some variables of the forests, including the number of trees, number of logs, number of standing dead trees, leaf litter depth, percentage of canopy opening, the distance to the nearest stream (igarapé), and altitude.

We tested the null hypothesis of no differences between the variation on forest structure components where birds were captured, and randomly selected locations within the reserve. We believe that the variables selected may be important because i) woodcreepers depend on vertical support or tree trunks for foraging, therefore areas with more trees could be more attractive to woodcreepers; ii) the abundance of logs and snags may provide more area for foraging and nesting; iii) although woodcreepers are essentially arboreal, areas with more leaf litter may have higher arthropod abundance; iv) canopy opening allowing higher light incidence may increase plant production and attract more insects than shaded sites; $v$ ) sites near streams (igarapé) are more humid and may have higher abundance of arthropods than sites away from igarapés; and vi) altitude is directly related to soil components, which affect the whole vegetation in the area.

\section{STUDY SITE}

The study was conducted between January 2002 and July 2004 at Reserva Florestal Ducke (02' 55', 03o 01' S; 59 53', $\left.59^{\circ} 59^{\prime} \mathrm{W}\right)$, a 10.000 -ha reserve, located $30 \mathrm{~km}$ north of Manaus. Mean annual precipitation is $2.286 \mathrm{~mm}$. The rainy season is mostly between November and May and the dry season between June and October.

In the reserve there are two drainage water-basins divided by a central ridge. Larger streams at the eastern side of the reserve run into the Amazon River tributaries, whereas streams on the western side drain into the Negro River tributaries (Ribeiro $e t$ al., 1999).

The dominant vegetation is primary Terra Firme forest, which is never seasonally inundated by river fluctuations. Soils are composed of oxysols, and small streams are abundant in the area, which is highly irregular and undulated with plateaus reaching altitudes of $140 \mathrm{~m}$ (Ribeiro et al., 1999).

\section{METHODS}

In order to record the occurence and local abundance of Dendrocincla fuliginosa and D. merula, we sampled the forest understory using mist-nets, which we complemented with acoustic surveys in part of the reserve. Birds were captured using 20 mist-nets (12 m length, $2.5 \mathrm{~m}$ height, and $2.5 \mathrm{~m}$ mesh) positioned in a continuous line covering $240 \mathrm{~m}$. The reserve has a grid of trails formed by two perpendicular sets of trails that creates $721-\mathrm{km}$ transects, one $\mathrm{km}$ apart from one another, covering 6400 ha. We placed fifty-one lines of nets systematically located in the median point of these transects. Trails are numbered and marked every $100 \mathrm{~m}$. 
Mist-nets were opened between 6:00 am and 01:00 pm, during two consecutive days. Captured birds were identified and marked with numbered aluminum bands (CEMAVE Center of Bird Migration, IBAMA, Brazil). Recaptured birds were not included in the analyses. Standardized bird measurements (total body length, culmen, wing, tail, tarsus, and mass) were taken using a caliper ( $1 \mathrm{~mm}$ precision) and Pesola spring scales ( $0.1 \mathrm{~g}$ precision). To standardize sampling effort, we consider each mist net line as our sample unity.

One of us (LNN) performed acoustic surveys to complement mist-netting data, sampling 22 transects already sampled with mist-nets. LNN did general surveys, where bird vocalizations were tape-recorded, and the exact location of each species was recorded. These transects were surveyed by walking through the trails slowly, and covering $1 \mathrm{~km}$ twice from 5:30 to $10 \mathrm{AM}$. Data obtained from these transects were later used to verify the occurrence of the bird species in question in areas already sampled with mist-nets. No playback was used during the surveys, and to avoid double counting, birds of the same species were recorded only once in the same general spot.

\section{RECORDING THE FOREST STRUCTURE COMPONENTS}

We established $50 \times 50 \mathrm{~m}$ plots at the same sites where mistnets were located. Within these plots, we quantified the following forest structure components and features of the landscape, including: 1) number of trees (diameter at breast height - DBH $>10 \mathrm{~cm}$ ); 2) number of logs; 3) number of snags; 4) leaf litter depth; 5) percentage of canopy opening; 6) distance to the nearest stream (igarapé); and 7) altitude.

We used the number of trees ( $\mathrm{DBH}>10 \mathrm{~cm}), \operatorname{logs}$ (diameter $>20 \mathrm{~cm}$ ), and snags, as a measurement of their abundance in the analyses. Litter depth was recorded by inserting a knife blade in the forest floor and counting the number of impaled dead leafs. We recorded the leaf litter depth on the four corners and at the center of 21 subplots of $1 \mathrm{~m}^{2}, 10 \mathrm{~m}$ equidistant one from another, with 20 sub-plots distributed along the sides and one at the center of each $50 \times 50 \mathrm{~m}$ plot. The mean value of the subplots was used in the analyses. We recorded forest canopy openness using a Spherical Crown Densiometer (Concave Mode C - Robert E. Lemonn, Forest Densiometer, 5733 SE Cornell Dr. - Bartlesville, OK, USA). We make four readings (north, south, east, and west) at the corners and center the plots. According to the instrument recommendations we multiplied each reading by 1.04 , and the mean value of the measurements was used in the analyses. Distance to the nearest stream and altitude were collected from a topographic map already available.

\section{STATISTICAL ANALYSES}

Pearson correlation matrix was constructed to verify correlation significance among forest structure components (independent variables). In those cases where independent variables were significantly correlated, these were used in different statistical models. We used multiple logistic regression analyses to investigate the effects of forest structure components on bird occurence for each species (presence/absence). The effects of forest structure components on abundance of each bird species were evaluated using models of multiple linear regressions, where the dependent variable was the abundance of each bird species. These analyses were all performed using the Systat statistical package software (Wilkinson, 1998).

\section{RESULTS}

\section{CORRELATIONS AMONG FOREST STRUCTURE COMPONENTS}

To avoid using correlated variables in the same model, we included abundance of trees, logs, and snags, leaf litter depth, and distance to the nearest stream in one model, and percentage of canopy opening and altitude, in another one (Table 1).

The abundance of trees in the plots $(\mathrm{N}=51)$ ranged from 64 to 228 (mean $=131.8$ trees), where that of logs ranged from 5 to 38 (mean $=11.3)$, and of snags varied from 0 to 11 (mean = 4.9). Mean leaf litter depth in the plots varied from 1.4 to 4.6 leaves, with an overall plot mean of 3.4 leaves. The mean percentage of canopy opening varied from 2.6 to $19.4($ mean = 9.5). The altitude varied from 38.7 to $114.7 \mathrm{~m}$ (mean $=76.5$ ), and the distance to the nearest stream (igarapé) varied from $0 \mathrm{~m}$ to $571 \mathrm{~m}$ (mean $=207.3 \mathrm{~m})$.

\section{OCCURENCE OF Dendrocincla fuliginosa AND D. merula}

Overall, we captured 74 individuals of Dendrocincla fuliginosa and 53 individuals of $D$. merula along the mist-nets. D. fuliginosa was present in $68.6 \%$ of the mist-netting transects (ranging from 0 to 8 individuals/transect), and $D$. merula was present in $51.9 \%$ (ranging from 0 to 6 individuals/transect). In the acoustic censuses $D$. fuliginos accurred in 11 transects, whereas D. merula was not recorded in any of them (Figure 1).

Sexual dimorphism is not apparent in either species, and at least $93 \%$ of $D$. fuliginosa and $91 \%$ of D. merula individuals were adults. In general body length measurements were similar between both species, but they differed in body mass (D. merula being notably larger than $D$. fuliginosa), (Table 2).

\section{EFFECTS OF FOREST STRUCTURE COMPONENTS IN THE OCCURENCE AND ABUNDANCE OF Dendrocincla fuliginosa}

Variations in altitude were significantly related to the occurrence of Dendrocincla fuliginosa (Multiple logistic regression analyses, McFadden's Rho-Squared (MRS) $=0.071, \mathrm{~N}=51, \mathrm{~T}$ $=2.029, \mathrm{p}=0.042)$, indicating that $D$. fuliginos $a$ prefers plateaus to lowland and flooded areas. The occurence of individuals of this species was not significantly affected by the other forest structure components, such as abundance of trees (MRS $=0.077$; $\mathrm{N}=51 ; \mathrm{T}=1.300 ; \mathrm{p}=0.193)$, abundance of $\operatorname{logs}(\mathrm{MRS}=0.077$; $\mathrm{N}=51 ; \mathrm{T}=1.153 ; \mathrm{p}=0.249$ ), abundance of snags (MRS = 


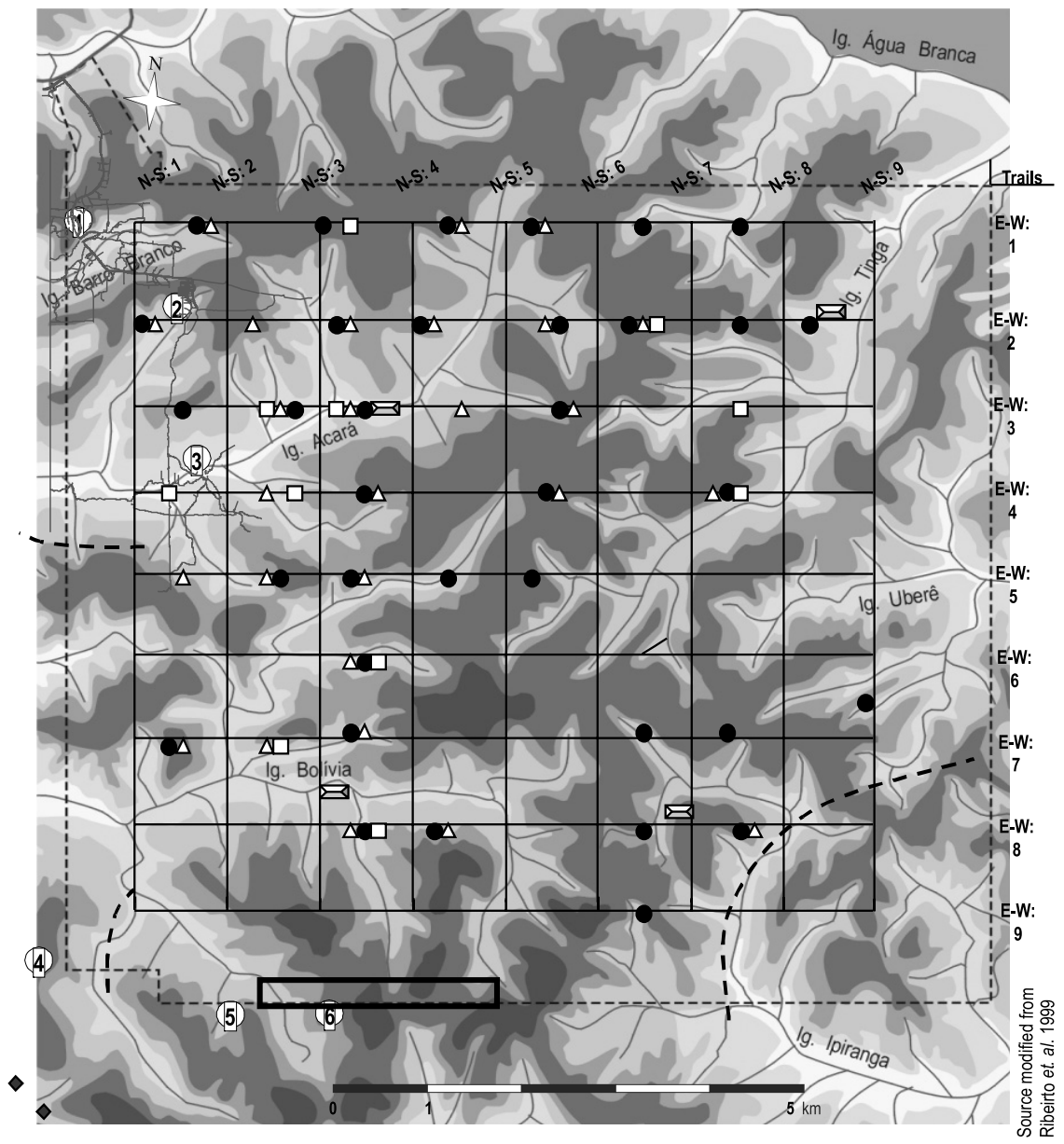

\section{- - - Reserve limits \\ - - Trail Sistem \\ _ - - Trail of local residents \\ - Botanical garden \\ 曰-Permanent camp sites}

1 - Home facilities

2 - Tower

3 - Acará camp site

4 - Sabiá Base 3

5. Sabiá Base 1

6 - Sabiá Base 2

Altitude

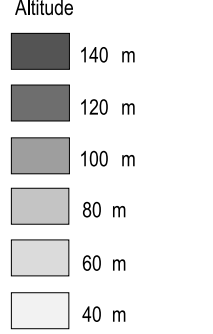

Figure 1 - Occurence of individuals of Dendrocincla fuliginosa (closed circles) and Dendrocincla merula (triangles) captured in the mist nets and Dendrocincla fuliginosa recorded in the acoustic surveys (squares) at the Reserva Ducke, Manaus.
Table 1 - Pearson correlation matrix for the forest structure components, tree abundance (TA), snags abundance (SA), forest logs abundance $(L A)$, proximity to streams (PS), leaflitter depth (LD), altitude (ALT), canopy opening $(\mathrm{CO})$ recorded in areas with and without the occurrence of the two woodcreepers Dendrocincla fuliginosa and Dendrocincla merula, in Reserva Ducke, Manaus

\begin{tabular}{|c|c|c|c|c|c|c|c|}
\hline & TA & SA & LA & LD & ALT (m) & PS (m) & CO (\%) \\
\hline TA & 1.000 & & & & & & \\
\hline SA & -0.093 & 1.000 & & & & & \\
\hline LA & 0.128 & -0.323 & 1.000 & & & & \\
\hline LB & 0.151 & 0.294 & -0.338 & 1.000 & & & \\
\hline ALT (m) & 0.162 & -0.117 & 0.136 & -0.388 & 1000 & & \\
\hline PS (m) & -0.062 & 0.097 & 0.048 & -0.136 & $0.534^{*}$ & 1.000 & \\
\hline CO $(\%)$ & 0.245 & $0.520^{*}$ & $-0.432^{*}$ & $0.535^{\star}$ & -0.314 & -0.189 & 1.000 \\
\hline
\end{tabular}

* The asteriscs corresponds to the statistical significance of $p<0.05$ resulting from the Bonferroni probability matrix used to evaluate how strong and significant were the correlations among the independent variables (forest structure components).
Table 2 - Body linear dimensions and weight of Dendrocincla fuliginosa and Dendrocincla merula in Reserva Ducke, Manaus.

\begin{tabular}{lll}
\hline Species & D. fuliginosa & D. merula \\
\hline & Mean \pm Standard deviation & Mean \pm Standard deviation \\
Body length $(\mathrm{cm})$ & $23.6 \pm 2.55(66)$ & $21.3 \pm 3.6(43)$ \\
Culmen $(\mathrm{cm})$ & $3.2 \pm 3.42(69)$ & $2.5 \pm 0.4(45)$ \\
Wing length (cm) & $10.9 \pm 0.9(69)$ & $10.3 \pm 1.6(45)$ \\
Tail length (cm) & $9.2 \pm 1.3(67)$ & $7.5 \pm 1.4(42)$ \\
Tarsus length (cm) & $2.6 \pm 0.4(61)$ & $2.7 \pm 0.4(45)$ \\
Weight $(\mathrm{g})$ & $38.4 \pm 8.6(69)$ & $51.5 \pm 6.3(45)$ \\
\hline
\end{tabular}

*Number in parenthesis is sample size $(\mathrm{N})$. These $\mathrm{N}$ values are different, because some birds escaped before we had finished the measurements of their dimensions. 

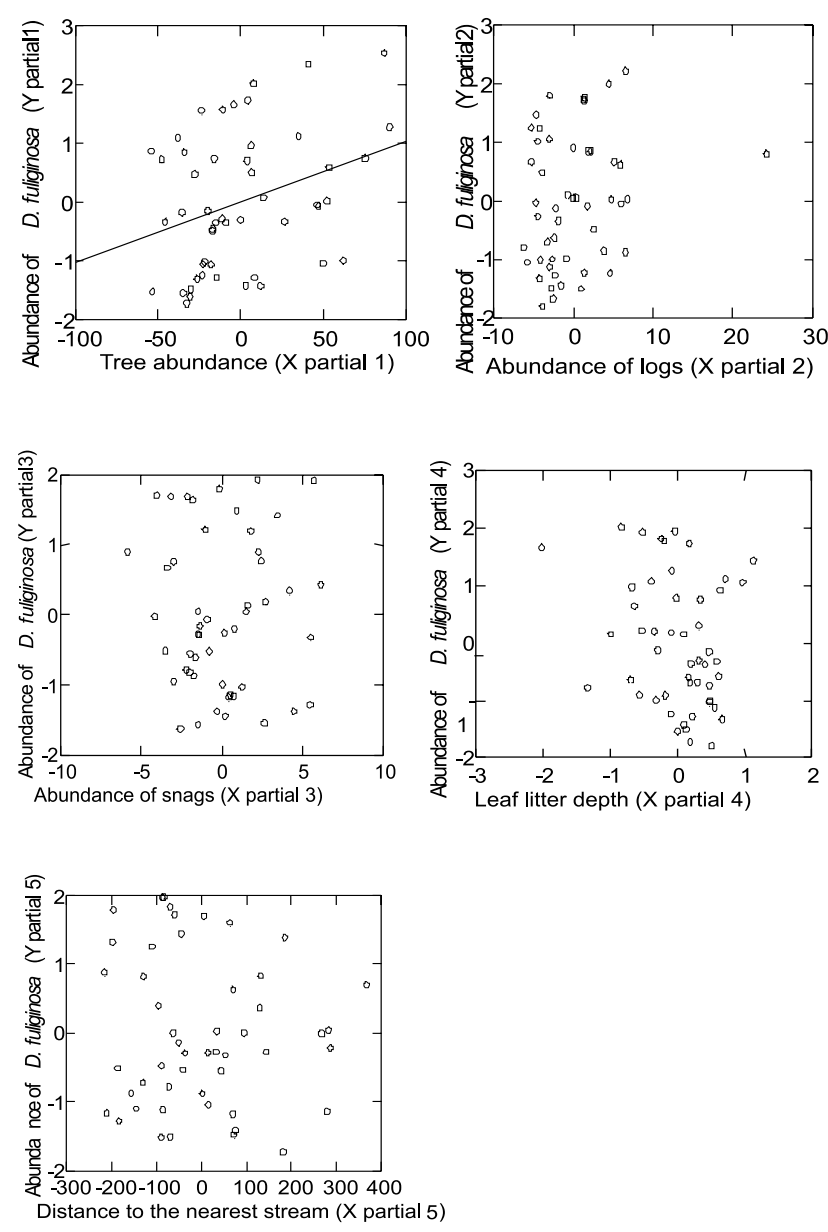

Figure 2 - Partials of multiple linear regression on abundance of Dendrocincla fuliginosa variation in relation to forest structure components: tree abundance, abundance of logs, abundance of snags, leaf litter depth and the distance to the nearest stream. Some numbers in the axis are negative because the partial regression represents the deviation of the expected results, if all the other independent variables are kept in their observed means.

$0.077 ; \mathrm{N}=51 ; \mathrm{T}=-0.232 ; \mathrm{p}=0.816)$, leaf litter depth $(\mathrm{MRS}=$ $0.077 ; \mathrm{N}=51 ; \mathrm{T}=-0.185 ; \mathrm{p}=0.853)$, distance to the nearest stream $(\mathrm{MRS}=0.077 ; \mathrm{N}=51 ; \mathrm{T}=0.969 ; \mathrm{p}=0.333)$ or mean percentage of canopy opening $(\mathrm{MRS}=0.071 ; \mathrm{N}=51 ; \mathrm{T}=0.536$; $\mathrm{p}=0.592$ )

D. fuliginosa was more abundant in areas with higher abundance of trees (Multiple linear regression analysis, $\mathrm{R}^{2}=$ $0.151, \mathrm{~N}=51, \mathrm{~T}=2.303, \mathrm{p}=0.026$, Figure 2), but was not significantly affected by other forest structure components (Figures 2 and 3), such as abundance of logs $\left(\mathrm{R}^{2}=0.151, \mathrm{~N}=\right.$ $51, \mathrm{~T}=1.413, \mathrm{p}=0.165)$, abundance of snags $\left(\mathrm{R}^{2}=0.151, \mathrm{~N}\right.$ $=51, \mathrm{~T}=-0.016, \mathrm{p}=0.987)$, leaf litter depth $\left(\mathrm{R}^{2}=0.151, \mathrm{~N}=\right.$ $51, \mathrm{~T}=-1.589, \mathrm{p}=0.119)$, distance to the nearest stream $\left(\mathrm{R}^{2}=\right.$ $0.151, \mathrm{~N}=51, \mathrm{~T}=-0.464, \mathrm{p}=0.645)$, mean canopy opening $\left(\mathrm{R}^{2}=0.036, \mathrm{~N}=51, \mathrm{~T}=-0.935, \mathrm{p}=0.354\right)$, or altitude $\left(\mathrm{R}^{2}=\right.$ $0.036, \mathrm{~N}=51, \mathrm{~T}=0.608, \mathrm{p}=0.546$ ).

\section{EFFECTS OF FOREST STRUCTURE COMPONENTS IN THE} OCCURENCE AND ABUNDANCE OF Dendrocincla merula

Dendrocincla merula occurred significantly more often in areas with lower forest tree abundance (Multiple logistic regression analysis, $\mathrm{MRS}=0.214, \mathrm{~N}=51, \mathrm{~T}=-2.555, \mathrm{p}=$ $0.011)$. There was also an inverse relationship between mean percentage of canopy opening and bird occurence (MRS = $0.057, \mathrm{~N}=51, \mathrm{~T}=-1.904, \mathrm{p}=0.057)$, suggesting that this bird species is more frequent in more shaded areas. The occurence of $D$. merula was not significantly affected by other forest structure components, such as abundance of logs $(\mathrm{MRS}=0.214 ; \mathrm{N}=51$; $\mathrm{T}=1.350 ; \mathrm{p}=0.177)$, abundance of snags $(\mathrm{MRS}=0.214 ; \mathrm{N}=$ $51 ; \mathrm{T}=0.556, \mathrm{p}=0.578)$, leaf litter depth $(\mathrm{MRS}=0.214 ; \mathrm{N}=$ $51 ; \mathrm{T}=-1.188 ; \mathrm{p}=0.235)$, distance to the nearest stream (MRS $=0.214 ; \mathrm{N}=51 ; \mathrm{T}=1.003 ; \mathrm{p}=0.316)$, or altitude $(\mathrm{MRS}=$ $0.057 ; \mathrm{N}=51 ; \mathrm{T}=-0.785 ; \mathrm{p}=0.433)$.

We found a significant inverse relationship between the abundance of $D$. merula, and the abundance of trees (Multiple linear regression analysis, $\mathrm{R}^{2}=0.231, \mathrm{~N}=51, \mathrm{~T}=-2.754, \mathrm{p}=$ 0.009 , Figure 4$)$ and the mean percentage of canopy opening $\left(\mathrm{R}^{2}=0.179, \mathrm{~N}=51, \mathrm{~T}=-3.090, \mathrm{p}=0.003\right.$, Figure 5).
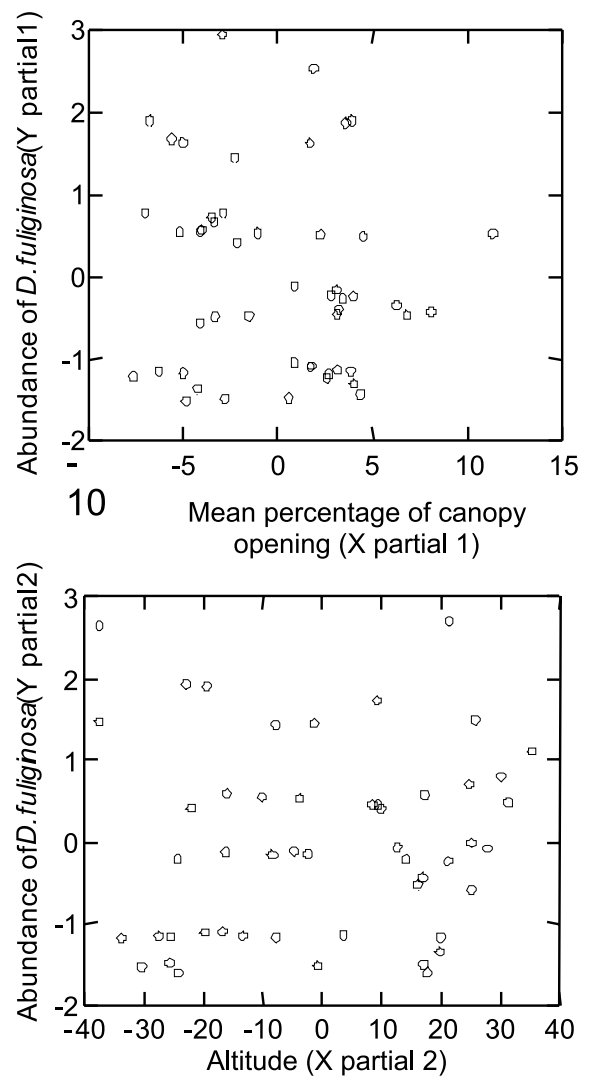

Figure 3 - Partials of multiple linear regression on abundance of Dendrocincla fuliginosa variation in relation to forest structure components: mean percentage of canopy opening and altitude. 

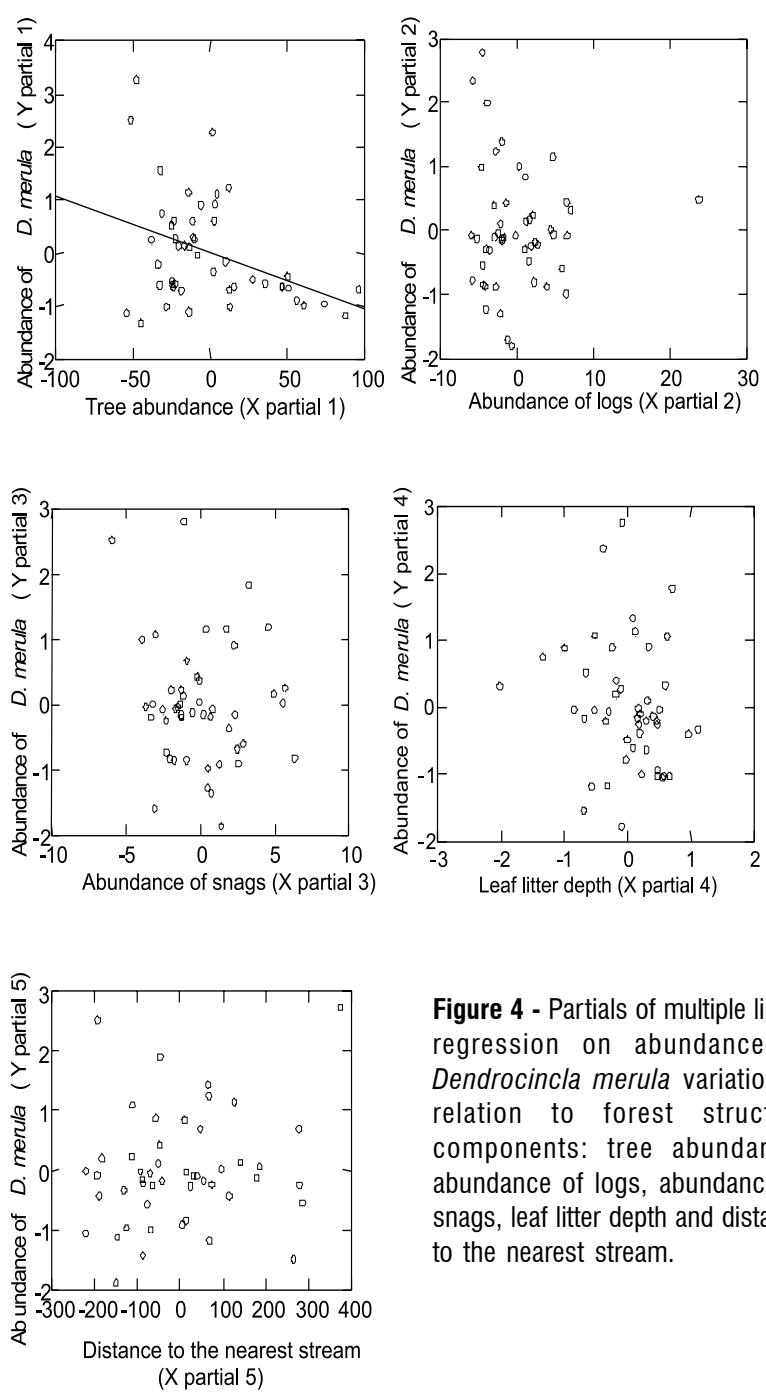

Figure 4 - Partials of multiple linear regression on abundance of Dendrocincla merula variation in relation to forest structure components: tree abundance, abundance of logs, abundance of snags, leaf litter depth and distance to the nearest stream.

The abundance of $D$. merula was not significantly affected by other forest structure components (Figures 4 and 5), such as abundance of logs $\left(\mathrm{R}^{2}=0.231, \mathrm{~N}=51, \mathrm{~T}=-0.245, \mathrm{p}=0.807\right)$, abundance of snags $\left(\mathrm{R}^{2}=0.231, \mathrm{~N}=51, \mathrm{~T}=-0.760, \mathrm{p}=\right.$ $0.452)$, leaf litter depth $\left(\mathrm{R}^{2}=0.231, \mathrm{~N}=51, \mathrm{~T}=-1.030, \mathrm{p}=\right.$ $0.309)$, distance to the nearest stream $\left(\mathrm{R}^{2}=0.231, \mathrm{~N}=51, \mathrm{~T}=\right.$ 1.209, $\mathrm{p}=0.233)$, or altitude $\left(\mathrm{R}^{2}=0.179, \mathrm{~N}=51, \mathrm{~T}=-0.313\right.$, $\mathrm{p}=0.756)$.

\section{DISCUSSION}

Until recently, studies have focused on bird species distribution and richness in relation to the number of forest vertical vegetation layers; the more vegetation layers, the more bird species the forest can accommodate (MacArthur \& MacArthur, 1961). Although this seems to be valid for many bird communities in temperate regions, it may not apply to the tropics (Terborgh, 1985; Pearson, 1977; Bierregaard, 1990).
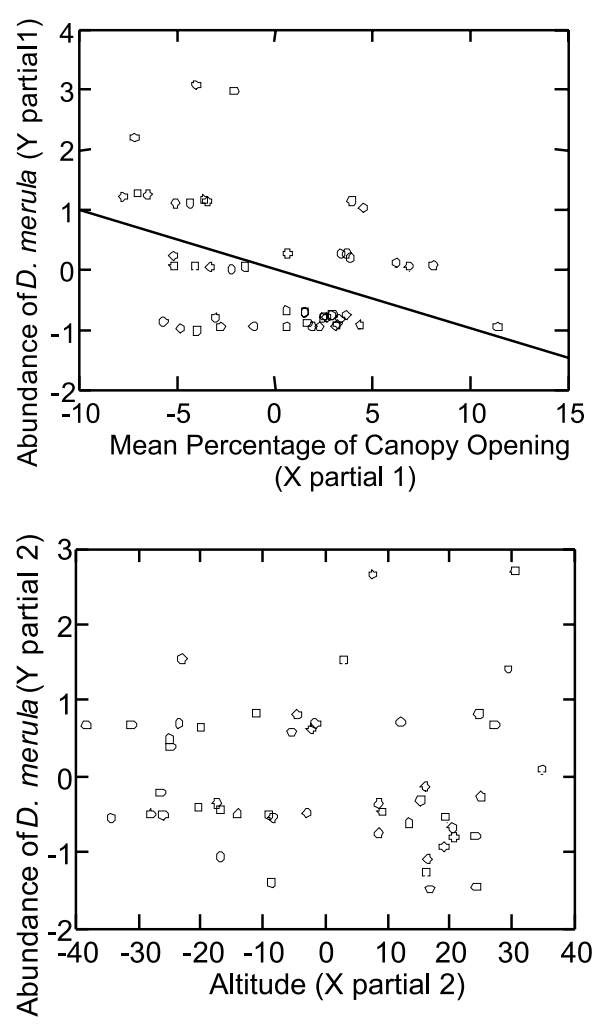

Figure 5 - Partials of multiple linear regression on abundance of Dendrocincla fuliginosa variation in relation to forest structure components: mean percentage of canopy opening and altitude.

In general, studies in neotropical forests have concentrated in analyzing factors affecting bird species richness and their distribution in relation to the various habitats (Remsen $\&$ Parker, 1983; Terborgh, 1985), and the effects of vegetation structure on bird guilds or communities (Pearson, 1975; Howe \& Smallwood, 1982, Terborgh et al., 1990; Loiselle \& Blake, 1991). However, few studies have investigated how the natural variation in the components of habitat structure affects the distribution and abundance of individual bird species (but see Aleixo, 1999; Cintra, 1997; Guilherme \& Cintra, 2001).

According to our results, the two species of Dendrocincla appear to concentrate their activities in the western part of the Reserve (Figure 1). The two bird species were recorded in at least $68 \%$ of the sampled sites, overlaping significantly in terms of areas used; both being recorded in at least $50 \%$ of the sampled sites (Figure 1).

Willis (1977) found that $D$. fuliginosa and D. merula occurred mainly in plateaus. Woodcreepers are known to be relatively sedentary, however, these two species may perform local movements and visit other areas in the reserve. Females of both species can move over areas of $2-3 \mathrm{~km}$ across, and even settled females raising juveniles can overlap widely on their territories and distribution, whereas non-breeding males may overlap in their home ranges (Willis 1972b, 1979). 
Our results support the conclusion that some components of the landscape and the forest structure are determinants of the occurrence and abundance of the two woodcreepers species we studied. The spatial variation in topographic conditions and tree density have influenced the occurrence and abundance of Dendrocincla fuliginosa; and spatial variation in tree density and forest canopy opening affected Dendrocincla merula. This may be expected since insectivorous birds can be very selective in the type of landscapes, habitats, trees, perch positions and foraging techniques (Stouffer \& Bierregaard, 1995; Cintra, 1997). Other woodcreeper species that we studied in the same area were also affected by the structure of the forest. For instance, Glyphorhynchus spirurus was more abundant in areas with lower density of trees, lower abundance of logs, and higher canopy opening. Similarly, Xiphorhynchus pardalotus was more abundant in plateaus away from streams (unpubl. data). Additionally, data from the Atlantic forest suggests that Sittasomus griseicapillus (a species also present in our study area) is more abundant at higher elevations (Aleixo, 1999).

The abundance of woodcreepers and other insectivorous birds such as tyrant flycatchers and antbirds has also been found to be affected by the spatial variation in the leaf litter and by the abundance of arthropods (Pearson, 1977; Pearson \& Derr 1986), tree height (Cintra, 1997), species differences in diet (Chapman \& Rosenberg, 1991), and competition for food and spots to forage (Pierpoint, 1986).

We found that the abundance of $D$. fuliginosa was higher in areas with more trees, suggesting that this species, by being essentially arboreal, as most woodcreepers, depends on vertical support for foraging (Orians, 1969). Areas with higher abundance of trees may be more intensively used for nesting, foraging or even looking for shelter.

$D$. merula occurence was inversely related to the abundance of trees. This species has a larger body mass than $D$. fuliginosa (Table 2) and might be less efficient in flight maneuvers. This could help to partially explain why we found $D$. merula using areas with open understory in the forest. In these areas less flight maneuvers are needed during the relatively long and local movements. In addition D. merula is "less adept at arboreal foraging, with less stiffened rectrices than other woodcreepers and more "clumsy", sallying to substrates above the ground" (Willis, 1979; Chapman \& Rosenberg, 1991).

Banks Leite (2004) studying bird community dynamics in our study area found that the composition of insectivorous bird assemblages was significantly correlated with tree-fall gaps, which may be due to the availability of illuminated spots with roosts and perches there (which probably are used for better detection of insects flying by) than in the continuous forest understory. We do not know how often woodcreepers visit gaps, and it seems that they do not like areas with high tree density. In fact, our results suggest that $D$. merula prefers areas with lower abundance of trees and a continuous shaded understory. At Reserva Ducke, Willis (1979) observed that D. merula preferred the open forest undergrowth of upland woods and mention that individuals of this species concentrate in these areas to follow large ant swarms. Our results suggest that variations in altitude can also affect the occurrence of $D$. fuliginosa, indicating that this species may be using plateaus more often than the bottom of the valleys.

The lack of correlation between the occurence and abundance of the two species of Dendrocincla here analyzed and other forest structure components suggest that the factors governing microhabitat use and habitat selection are complex and still need to be determined.

Our results indicate that each species of woodcreeper use the forest differently. This could be due to competition for good spots to forage or simply due to interspecific differences in microhabitat preferences (Pierpoint, 1986). At Reserva Ducke, $D$. fuliginosa forages on arthropods on the ground, leaf litter, and tree trunks (RC pers.obs), whereas D. merula, being an obligatory army ant follower, concentrates its foraging on catching arthropods in the leaf litter on the forest floor (Willis, 1979).

In Panama, Willis (1979) found that $D$. fuliginosa forages on the ground, but also on tree trunks, roots, stems, lianas, the surface of leaves, twigs, dead leaves, on the air, and also following army ants to catch prey. In Bolivia and Peru, D. fuliginosa was seen mostly from 5 to $8 \mathrm{~m}$ above ground (Chapman $\&$ Rosenberg, 1991).D. merula perches within $1 \mathrm{~m}$ of the ground, and $90 \%$ of its foraging consists of sallies to the ground in pursuit of arthropods fleeing ants (Willis, 1979; Chapman \& Rosenberg, 1991). Intersepecific aggressive behaviors have been seen between both species when following army ants; $D$. merula being dominant and displacing $D$. fuliginosa to higher perches when the availability of prey escaping from the army ants is lower (Willis, 1979).

Chapman \& Rosenberg (1991) suggested that the segregation, both in foraging height and substrate use may have resulted in a shift in the proportions of main prey items, with more spiders and roaches in the diet of D. merula (associated with ground-foraging) and more beetles associated with foraging on trunks and vines in D. fuliginosa. Additionally, woodcreepers are territorial and aggressive birds, and direct interactions are frequently reported (John Terborgh, pers. com.; Willis, 1966, 1972b, 1978, 1979; RC, pers. obs.).

Dendrocincla woodcreepers are relatively long-lived species (individuals over 10 years old have been found); therefore, it is possible that they learn how to maximize the use of the forest (Snow \& Lill, 1974). Although these two woodcreepers differ 
in their use of substrates, foraging space and diet, their overlap in diet may represent a case of complementarity of niches (Chapman \& Rosenberg, 1991).

We recorded individuals of Dendrocincla fuliginosa joining mixed-species flocks and flying close to $1 \mathrm{~m}$ above the ground, which may have facilitated their capture in the mist nets. This suggests that mist-nets represent an appropriate method for studying the occurence of understory woodcreepers in the forest. During the study period, at least nine other woodcreeper species were captured by mist-nets, representing about two thirds of the 14 species present in the reserve (Willis,1977).

Habitat disturbances due to deforestation may affect negatively woodcreeper populations. Thirty kilometers from our study area, Harper (1989) noticed a population decline of $D$. fuliginosa and $D$. merula, in forest fragments. In fact, woodcreepers seem to be very sensitive to changes in the forest structure, principally when tree abundance is reduced. In French Guiana, Thiolay (1992) reported that even 8-12 years after logging, the abundance of $D$. fuliginosa and $D$. merula was 7.7 times lower in logged areas than in undisturbed forest. In the Brazilian Atlantic Forest, Olivaceous Woodcreeper (Sittasomus griseicapillus) showed significantly higher abundance in primary forest than in areas of selective logging (Aleixo,1999). The results of this study indicate that these three species can be affected by the forest structure when forest management is not adequate or is too intense (Thiolay, 1992; Aleixo, 1999; Guilherme \& Cintra, 2001).

On the other hand, some years after fragmentation Stouffer \& Bierregaard (1995) found that $D$. fuliginosa occurence was stable in forest fragments and this probably reflects its mode of foraging at the fragment's edges and secondary vegetation (Willis, 1972a,b, 1977). Although Dendrocincla species are reluctant to invade areas of secondary vegetation or to cross open areas (Terborgh \& Weske,1969), they have been seen visiting the forest edge and even tree crop plantations (Willis 1972a, 1979). This behavioral flexibility may allow this species to occur where other woodcreepers were extirpated; $D$. merula, being an obligate ant-follower may be more vulnerable. Therefore, local variation in the forest structure may contribute to the coexistence of congeneric species and may help to maintain local alpha diversity.

\section{ACKNOWLEDGEMENTS}

We want to thank Obed Barros, Sidnei Dantas, Marlison Ferreira, Lucas Mergulhão and Francisco Marques Bezerra for their competent field assistance in helping us with the mist nets and with measurements of forest structure components. This study was supported by Instituto Nacional de Pesquisas da Amazônia, CNPq-PNOPg, CNPq-PELD.

\section{LITERATURE CITED}

Aleixo, A. 1999. Effects of selective logging on a bird community in the Brazilian Atlantic Forest. Condor 101: 537-548.

Banks Leite, C. C. 2004. Influência dos componentes estruturais de clareiras na comunidade de aves na Amazônia Central. Master's Thesis. Instituto Nacional de pesquisas da Amazônia/Fundação Universidade do Amazonas, Manaus, Amazonas. 71pp.

Bierregaard, R. 1990. Avian communities in the understory of Amazonian forest fragments. In: Alan Keast (Ed.). Biogeography and Ecology of forest bird communities SPB Academic Publishing by The Hague, The Netherlands. p. 333-343.

Chapman, A.; Rosenberg, K.V.1991. Diets of four sympatric amazonian woodcreepers (Dendrocolaptidae). Condor, 93: 904915.

Cintra, R. 1997. Spatial Distribution and foraging tactics of tyrant flycatchers in two habitats in the Brazilian Amazon. Studies on Neotropical Fauna and Environment, 32: 17-27.

Cohn-Haft, M.; Whittaker, A.; Stouffer, P.C. 1997. A new look at the "species poor" central amazon: the avifauna north of Manaus, Brazil. Ornithological Monographs, 48: 205-235.

Guilherme, E.; Cintra, R. 2001. Effects of intensity and age of selective logging and tree girdling on an understory bird community composition in central Amazonia, Brazil. Ecotropica, 7: 77-92.

Harper, L. H. 1989. The persistence of ant-following birds in small Amazonian forest fragments. Acta Amazonica, 19 (único) : 249263.

Howe, H. F.; Smallwood, J. 1982. Ecology of seed dispersal. Ann. Rev. Ecol. Syst. 13: 201-228.

Johns, A. D. 1991. Responses of Amazonian rain forest birds to habitat modification. Journal of Tropical Ecology, 7: 417-437.

Karr, J.R.; Roth, R. R. 1971. Vegetation structure and avian diversity in several new world areas. American Naturalist, $105: 423-435$.

Levey, D. J. 1988. Spatial and temporal variation in Costa Rica fruit and fruit-eating bird abundance. Ecological Monographs, 58: 251269.

Loisselle, B. A. 1988. Bird abundance and seasonality in a Costa Rican lowland forest canopy. Condor, 90: 761-772.

Loisselle, B. A.; Blake, J. G. 1991. Temporal variation in birds and fruits along an elevational gradient in Costa Rica. Ecology, 72(1): 180-193.

MacArthur, R.; MacArthur, J. W. 1961. On birds species diversity. Ecology, 42(3): 594-598.

MacArthur, R.; Recher, H.; Cody, M. 1966. On the relation between habitat selection and species diversity. American Naturalist, 100(913): 319-332.

Manasse, R. S.; Howe, H. F. 1983. Competition for dispersal agents among tropical trees: influences of neighbors. Oecologia, 59: 185- 190. 
Martin, T. E. 1985. Selection of second-growth woodlands by frugivorous migrating birds in Panama: an effect of fruit size and plant density? Journal of Tropical Ecology, 1: 157-170.

Munn, C.A. 1985. Permanent canopy and understory flocks in Amazonia: species composition and population density, In: Buckley, P.A.; Foster, M.S.; Morton, E.S.; Ridgely, R.S; Burckley,F. G. (Eds.). Neotropical Ornithology. Ornithological Monograph No 36, p. 683-712.

Naranjo, L. G. 1992. Estructura da la avifauna en un area ganadera en el valle del Cauca, Colombia. Caldasia, 17: 55-66.

Orians, G. H. 1969. The number of birds species in some tropical forests. Ecology, 50(5): 783-801.

Pearson, D. L. 1975. The relation of foliage complexity to ecological diversity of three Amazonian bird communities. Condor 77: 453-466.

Pearson, D. L. 1977. Ecological relationship of small antbirds in Amazonian bird communities. Auk, 94: 283-292.

Pearson, D. L.; Derr, J. A. 1986. Seasonal patterns of lowland forest floor arthropod abundance in southern Peru. Biotropica, 18: 244246.

Pierpoint, N. 1986. Interspecific aggression and the ecology of woodcreepers (Aves: Dendrocolaptidae), PhD. Thesis, Princeton University, N.J.

Remsen, V. J., Jr.; Parker, T. A. III 1983. Contribution of rivercreated habitats to bird species richness in Amazonian. Biotropica, 15(3): 223-231.

Rey, P. J. 1995. Spatio-temporal variation in fruit and frugivorous bird abundance in olive orchards. Ecology, 75: 1625-1635.

Ribeiro, J. E. L. da S.; Hopkins, M. J. G.; Vincentini, A.; Sothers C. A.; Costa, M. A.; Brito, J. M. de; Souza, M A.D. de; Martins, L. H. P.; Lohmann, L. G.; Assunção, P. A. C. L.; Pereira, E. da C.; Silva, C. F. da; Mesquita, M. R.; Procópio, L. C. 1999. Flora da Reserva Duke - Guia de identificação das plantas vasculares de uma floresta de terra-firme na Amazônia Central. Instituto Nacional de Pesquisas da Amazônia. Manaus, Amazonas. 816pp.

Roth, R. R. 1976. Spatial heterogeneity and birds species diversity. Ecology, 57: 773-782.

Sick, H. 2001. Ornitologia Brasileira: Uma introdução. Editora Nova Fronteira, Rio de Janeiro, 912pp.

Snow, D.W.; A, Lill. 1974. Longevity records for some neotropical land birds. Condor, 76: 262-267.
Stouffer, P.C.; R.O Bierregaard, Jr. 1995. Use of forests fragments by understory insectivorous birds. Ecology, 76: 2429-2445.

Terborgh, J. 1985. Habitat selection in Amazonian birds. In: M. L Cody. (Ed). Habitat selection in birds. Academic Press Inc. New York. p.331-340.

Terborgh, J; Robinson, S. K.; Parker III, T. A ; Munn, C. A; Pierpont, N. 1990. Structure and organization of an amazonian forest bird community. Ecological Monographs, 60: 213-238

Terborgh, J; Weske, J. S. 1969. Colonization of secondary habitats by Peruvian birds. Ecology, 50(5): 765-782.

Thiollay, J.M. 1992. Influence of selective logging on bird species diversity in a Guianan rain forest. Conservation Biology, 6(1): 4763.

Wiens, J. A. 1973. Pattern and process in grassland communities. Ecological Monographs, 43: 237-270.

Wiens J.A.. 1974. Habitat heterogeneity and avian community structure in North American grasslands. American Midland Naturalist, 43: 237-270.

Wiens, J.A.; Rotenberry, J.T; Van Horne, B.1987. Habitat occupancy patterns of North American shrubsteppe birds: the effects of spatial scale. Oikos, 48: 132-147.

Willis, E. O. 1966. Interspecific competition and the foraging behaviour of Plain-brown Woodcreepers. Ecology 47: 667-672.

Willis, E. O. 1972a. The behavior of Spotted Antbirds. A. O. U. Monographs, 10, 162pp.

Willis, E. O. 1972b. The behaviour of Plain-brown Woodcreepers, Dendrocincla fuliginosa. Wilson Bulletin, 81: 377-420.

Willis, E. O.; Oniki, Y. 1978. Birds and army ants. Annual Review in Ecology and Systematics, 9: 243-263.

Willis, E. O. 1979. Behavior and ecology of two forms of Whitechinned Woodcreepers (Dendrocincla merula, Dendrocolaptidae) in Amazonia. Papeis Avulsos Zoologia S. Paulo, 33: 27-66.

Willis, E.O. 1977. Lista preliminar das aves da parte noroeste e áreas vizinhas da Reserva Ducke, Amazonas, Brasil. Revista Brasileira de Biologia, 37(3): 585-601.

Wilkinson, L. 1998. Systat: The system for statistics. SYSTAT Inc. Evanston, Illinois.

Recebido em 17/11/04

Aceito em 17/04/06 
Appendix I - Raw data on the occurrence and abundance of Dendrocincla fuliginosa and Dendrocincla merula and the forest structure components recorded in the study.

\begin{tabular}{|c|c|c|c|c|c|c|c|c|c|c|c|c|}
\hline LOCAL & DATE & $\mathrm{A}$ & $\mathrm{B}$ & C & $\mathrm{D}$ & $\mathrm{E}$ & $\mathrm{F}$ & $\mathrm{G}$ & $\mathrm{H}$ & 1 & J & $\mathrm{K}$ \\
\hline E-W1/1/0-250 & January & 0 & 0 & 0 & 0 & 115 & 5 & 7 & 2.7 & 5.1 & 285 & 99.9 \\
\hline$E-W 1 / 950-1300$ & March & 3 & 1 & 1 & 1 & 141 & 9 & 5 & 1.4 & 5.0 & 142 & 108.8 \\
\hline$E-W 1 / 2000-2300$ & March & 1 & 1 & 0 & 0 & 82 & 10 & 7 & 2.8 & 3.1 & 500 & 110.8 \\
\hline E-W1/3100-3400 & March & 2 & 1 & 2 & 1 & 110 & 8 & 6 & 3.9 & 6.2 & 71 & 71.2 \\
\hline$E-W 1 / 5500-5750$ & August & 1 & 1 & 0 & 0 & 188 & 6 & 2 & 3.9 & 13.0 & 71 & 63.4 \\
\hline E-W1/6600-6850 & August & 1 & 1 & 0 & 0 & 187 & 10 & 4 & 4.1 & 13.2 & 214 & 69.1 \\
\hline E-W1/7250-7500 & August & 0 & 0 & 0 & 0 & 115 & 7 & 2 & 4.0 & 13.1 & 35 & 44.2 \\
\hline$E-W 2 / 0-250$ & February & 2 & 1 & 4 & 1 & 83 & 6 & 4 & 3.2 & 4.3 & 0 & 92.5 \\
\hline E-W2/1000-1250 & February & 0 & 0 & 2 & 1 & 151 & 5 & 11 & 3.0 & 4.7 & 285 & 82.8 \\
\hline E-W2/2100-2350 & February & 2 & 1 & 4 & 1 & 121 & 9 & 0 & 3.0 & 4.8 & 571 & 114.7 \\
\hline E-W2/3000-3300 & March & 2 & 1 & 2 & 1 & 122 & 11 & 7 & 3.5 & 5.8 & 339 & 78.1 \\
\hline E-W2/4500-4750 & November & 1 & 1 & 1 & 1 & 111 & 21 & 1 & 4.0 & 16.5 & 228 & 92.0 \\
\hline E-W2/5250-5500 & August & 1 & 1 & 1 & 1 & 119 & 18 & 4 & 3.9 & 14.9 & 357 & 96.8 \\
\hline E-W2/6500-6800 & May & 1 & 1 & 0 & 0 & 151 & 9 & 4 & 3.9 & 11.9 & 464 & 87.4 \\
\hline E-W2/7250-7500 & August & 1 & 1 & 0 & 0 & 162 & 15 & 2 & 4.1 & 13.8 & 0 & 54.4 \\
\hline E-W3/550-800 & March & 3 & 1 & 0 & 0 & 161 & 9 & 6 & 4.6 & 3.7 & 71 & 77.1 \\
\hline$E-W 3 / 1600-1900$ & March & 3 & 1 & 2 & 1 & 117 & 15 & 0 & 3.5 & 4.5 & 214 & 46.3 \\
\hline E-W3/2250-2500 & October & 2 & 1 & 3 & 1 & 92 & 6 & 8 & 3.7 & 3.1 & 142 & 63.7 \\
\hline E-W3/3250-3500 & December & 0 & 0 & 0 & 0 & 64 & 10 & 2 & 2.7 & 13.2 & 71 & 58.1 \\
\hline E-W3/3500-3750 & November & 0 & 0 & 1 & 1 & 111 & 8 & 11 & 2.9 & 5.6 & 17 & 56.6 \\
\hline E-W3/4500-4750 & November & 2 & 1 & 1 & 1 & 105 & 8 & 5 & 4.1 & 4.2 & 357 & 93.6 \\
\hline E-W3/5500-5800 & May & 0 & 0 & 0 & 0 & 192 & 10 & 3 & 4.3 & 12.7 & 71 & 64.5 \\
\hline E-W3/6500-6800 & May & 0 & 0 & 0 & 0 & 118 & 11 & 2 & 4.1 & 12.6 & 178 & 38.7 \\
\hline E-W3/7500-7800 & May & 0 & 0 & 0 & 0 & 113 & 9 & 2 & 4.0 & 14.1 & 100 & 50.5 \\
\hline E-W4/500-800 & March & 0 & 0 & 0 & 0 & 98 & 19 & 3 & 3.9 & 13.0 & 71 & 46.4 \\
\hline E-W4/1600-1900 & March & 0 & 0 & 2 & 1 & 103 & 8 & 6 & 2.8 & 2.6 & 500 & 62.3 \\
\hline E-W4/3500-3750 & October & 0 & 0 & 0 & 0 & 97 & 6 & 7 & 2.5 & 2.8 & 142 & 103.8 \\
\hline$E-W 4 / 4300-4550$ & November & 1 & 1 & 1 & 1 & 120 & 8 & 6 & 2.9 & 4.5 & 250 & 99.8 \\
\hline E-W4/5250-5500 & November & 0 & 0 & 0 & 0 & 196 & 9 & 3 & 3.8 & 12.7 & 357 & 92.1 \\
\hline E-W4/6500-6850 & May & 1 & 1 & 1 & 1 & 122 & 15 & 2 & 4.0 & 11.9 & 142 & 49.0 \\
\hline E-W5/4250-4500 & October & 1 & 1 & 0 & 0 & 185 & 9 & 3 & 4.0 & 11.3 & 128 & 95.3 \\
\hline E-W5/3250-3500 & November & 2 & 1 & 0 & 0 & 201 & 9 & 2 & 3.3 & 19.3 & 128 & 98.1 \\
\hline E-W6/1500-1800 & August & 0 & 0 & 0 & 0 & 113 & 17 & 4 & 4.2 & 14.7 & 214 & 52.6 \\
\hline E-W6/2500-2800 & August & 1 & 1 & 1 & 1 & 130 & 16 & 9 & 3.9 & 14.0 & 178 & 65.6 \\
\hline E-W7/500-800 & April & 3 & 1 & 1 & 1 & 117 & 13 & 2 & 3.5 & 15.1 & 9 & 45.9 \\
\hline E-W7/1500-1800 & July & 0 & 0 & 2 & 1 & 135 & 17 & 4 & 3.7 & 13.5 & 286 & 74.7 \\
\hline E-W7/2500-2800 & August & 1 & 1 & 1 & 1 & 113 & 14 & 2 & 4.0 & 15.3 & 285 & 81.2 \\
\hline E-W7/5500-5800 & July & 2 & 1 & 0 & 0 & 151 & 14 & 11 & 3.4 & 10.1 & 357 & 100.6 \\
\hline E-W7/6500-6800 & July & 3 & 1 & 0 & 0 & 228 & 12 & 11 & 2.8 & 10.5 & 142 & 84.5 \\
\hline E-W8/2500-2750 & April & 8 & 1 & 5 & 1 & 87 & 22 & 4 & 3.8 & 15.3 & 285 & 56.2 \\
\hline E-W8/3500-3750 & April & 3 & 1 & 1 & 1 & 108 & 17 & 3 & 3.8 & 14.6 & 142 & 50.2 \\
\hline E-W8/5500-5800 & July & 4 & 1 & 0 & 0 & 211 & 11 & 5 & 2.8 & 9.9 & 285 & 97.5 \\
\hline E-W8/6500-6800 & July & 4 & 1 & 6 & 1 & 185 & 14 & 11 & 3.3 & 8.6 & 142 & 40.5 \\
\hline E-W9/6500-6800 & July & 2 & 1 & 0 & 0 & 188 & 9 & 8 & 3.0 & 6.9 & 250 & 97.5 \\
\hline E-W9/7350-7600 & September & 0 & 0 & 0 & 0 & 151 & 10 & 8 & 3.3 & 8.6 & 142 & 97.8 \\
\hline E-W9/5250-5500 & September & 2 & 1 & 0 & 0 & 109 & 11 & 7 & 3.3 & 7.2 & 0 & 63.9 \\
\hline E-W4/2500-2750 & January & 2 & 1 & 2 & 1 & 107 & 38 & 0 & 3.2 & 12.2 & 357 & 103.0 \\
\hline E-W5/1500-1750 & January & 2 & 1 & 1 & 1 & 123 & 7 & 3 & 2.7 & 2.9 & 286 & 95.9 \\
\hline
\end{tabular}




\section{ACTA}

AMAZONICA

ABUNDANCE OF TWO Dendrocincla WOODCREEPERS (AVES: DENDROCOLAPTIDAE)

IN RELATION TO FOREST STRUCTURE IN CENTRAL AMAZONIA

\section{Appendix I - Continuation}

\begin{tabular}{lllllllllllll}
\hline LOCAL & DATE & A & B & C & D & E & F & G & H & I & J & K \\
\hline E-W5/500-750 & January & 0 & 0 & 2 & 1 & 84 & 5 & 7 & 1.7 & 4.5 & 71 & 53.5 \\
E-W5/2500-2750 & January & 3 & 1 & 2 & 1 & 128 & 6 & 3 & 2.9 & 3.9 & 143 & 83.3 \\
E-W1/4000-4250 & January & 1 & 1 & 1 & 1 & 99 & 5 & 9 & 2.8 & 6.5 & 500 & 97.8 \\
\hline
\end{tabular}

$\mathrm{A}=$ Abundance of Dendrocincla fuliginosa $\mathrm{B}=$ Occurrence of Dendrocincla fuliginosa: $\mathrm{C}=$ Abundance of Dendrocincla merula $; \mathrm{D}=$ Occurrence of Dendrocincla merula; $\mathrm{E}=$ Abundance of tree; $F=$ Abundance of forest logs; $G=$ Abundance of snags; $H=$ Mean leaf litter depth; $I=$ Mean percentage of canopy opening; $J=$ Distance to the nearest stream $(m) ; K=$ Altitude $(m)$ 